New Zealand journal of industrial relations, 1991, 16, 211-231

\title{
ARTICLES
}

\section{Would the good employer please step forward? A discussion of the "good employer" concept in the State Sector Act 1988}

\author{
Peter Boxall*
}

The State Sector Act 1988 brings revolutionary change to public service personnel management and industrial relations. This paper analyzes the good employer principle contained in the Act against a backdrop of private and public sector thought in respect of good employment behaviour. The current model of public sector personnel management is termed "accountable management" and it is argued that any notion of the good employer must be a "bounded" one. A set of assumptions in terms of good employer attitudes is established, explored in terms of particular processes and policies and a general public service pattern of employee relations is suggested. Finally, the problems of assessing chief executive performance under the Act are discussed. The argument is made that the bounded nature of the good employer principle must be recognized in chief executive appraisal as must the fact that worthwhile change in employment relations is a long term endeavour. The process of becoming a good employer is never complete.

\section{Introduction}

The reforms of the fourth Labour Government (1984 -1990) in respect of state sector industrial relations and personnel management were, by any estimation, radical. The elimination of public service classifications, the notion of the unified career service, automatic wage linkages with the private sector and compulsory arbitration and their replacement with departmental ("enterprise-based") agreements and job concepts, collective bargaining and senior management contracts was, like the Public Service Act 1912, an exercise in revolution not evolution (Martin, 1988, p.1). Coupled with Labour's corporatization and privatization programme and associated redundancies, the reforms of pay fixing and employment arrangements have been playing a major role in the drive to create a more efficient state sector which is congruent with the broader need to improve the competitive performance of the New Zealand economy (Boston, 1987, 1988; Deane, 1989a, 1989b; Scott and Gorringe,1989; Harbridge and Walsh, 1989). Few revolutions, however, completely repudiate the past. The notion of the "good employer" contained in section 56 of the State Sector Act 1988 can be seen as an attempt to

* National Key Centre in Industrial Relations, Monash University, Clayton, Victoria 3168. 
maintain a link with the historic approach to public sector employment but encourage that tradition to be applied more flexibly and efficiently in individual departments of state. While the statute is specific about certain dimensions of the good employer principle (most notably the Equal Employment Opportunity (EEO) dimension), it essentially requires individual departments to put their own flesh on the bones - to develop a customized employing philosophy within the broad framework and give it expression in a consistent set of personnel policies. The performance review of each chief executive must include an assessment of their performance as a good employer (s.43) and members of the senior executive service (SES) are expected to be supportive of their department's effectiveness in this area (s.51).

The function of this article is to offer an analysis of the good employer provisions. First, because existing legal notions are inadequate to define good employment practice, an attempt is made to provide an historical overview of private sector management thought since the Industrial Revolution in respect of "good" employment behaviour. Second, key phases in the public sector tradition are examined. With these historical sketches as a backdrop, some assumptions in respect of the good employer concept are offered and the Act is explored in terms of specific processes and policies. A general pattern of public service employee relations is then suggested. Finally, the article engages in a discussion of the problem of assessing chief executive performance under the Act.

\section{Private sector management thought and the notion of the good employer}

While it is true that New Zealand courts, like courts elsewhere, have developed a concept of the "good and considerate" employer (Deeks and Boxall, 1989, p.177) or "good industrial practice" (Hughes, 1990, p.1929) in relation to the termination of employment, the role of the courts is not to establish a comprehensive theory of "good" employment that can be applied by employers in the totality of their dealings with staff. The decisions of New Zealand courts provide at best partial and fragmentary assessments of employment practice. Similarly, industrial relations statutes which attempt to regulate the production of substantive employment codes frequently provide much stability in employment relations but, again, cannot be considered as being in the business of providing a complete framework in respect of the notion. We must turn to management thought for anything approaching a satisfactory understanding of what it means to be a good employer and, here too, there are difficulties. Any attempt to define good employer behaviour involves value judgments as the State Sector Act recognizes when it states that:

... a "good employer" is an employer who operates a personnel policy containing provisions generally accepted as necessary for the fair and proper treatment of employees in all aspects of their employment... (s.56(2)) (emphasis added).

Herein lies the challenge of this novel statute. Practitioners and the judiciary (if ever called upon to do so) must interpret what is meant by "generally accepted as necessary for the fair and proper treatment of employees". How they might do this is the concern of this article. Behavioural science or industrial relations research is no substitute for the taking of certain philosophical positions although theoretical frameworks and research findings can assist managers to understand how employees think and feel and how certain actions and policies are likely to be received. At the end of the day, however, value judgments must still be made. This means that there is plenty of room for ethical argument. 
Despite the difficulties of securing moral agreement in our modern age of relative values (MacIntyre, 1987), a strong argument can be made that it is possible to identify particular schools of management thought over the last 100 years where a significant body of writers and practitioners have adopted a position which might be regarded as the "high moral ground" in respect of labour management. The intention of this article is not to describe these doctrines in depth (which has been done elsewhere) but to point to the trend in thought over that time.

\section{The welfare movement}

The first such body of thought is easily identified with the emergence of the welfare movement around the turn of the century, primarily in the UK (Crichton, 1968; McGivering, 1970) but also in the USA (Eilbirt, 1959; Miller and Coghill, 1961). The role of the British Quaker firms - particularly Rowntrees and Cadburys - was significant in propagating the view that the good employer acknowledges a moral duty to care for the well-being of its employees. The good employer does not treat workers as "factory hands" to be hired and fired at will in an environment of poor conditions and low security. Rather, they take steps to improve employee health, education, housing and capacity to earn. Welfare work was regarded "not simply as a set of techniques" but as "the expression of a spiritual outlook on life" (McGivering, 1970, p.180). Our contemporary Institutes of Personnel Management are the direct descendants of the associations formed by the early welfare workers. (The view is taken here that the American "human relations" movement associated with such names as Mayo, McGregor and Herzberg, does not essentially add much to the values espoused by the welfare movement but has encouraged the increased application of behavioural science technologies such as job enrichment.)

\section{Industrial pluralism}

Although benevolent, the welfare movement's fundamental paternalism cannot fail to be noted (and, similarly, the naivety of the human relations movement in respect of conflict of interest is easily criticized). While the welfarist approach survives in modified forms to the present day, and while some paternalism will always be embedded in the employment relationship, the desire of employees for independent representation of their interests through trade unions required the development of a modified doctrine of the good employer. This doctrine called "industrial pluralism" by Kahn-Freund (Davies and Freedland, 1983), acknowledges the right of unions to represent employees and advocates a positive approach by management to union relations. One of the greatest exponents of the doctrine and its implications, Hugh Clegg (1972, p.82-83), put it this way:

.... The "progressive" employer welcomes trade unions, encourages his (sic) workers to join them, perhaps grants them the security of a closed shop, takes pains to keep on good terms with the union officials, pays a full time elected secretary of the workers' side of the works council to devote his time to looking after the interests of the workers; and the reason for it is that he feels that willing cooperation can only arise out of independence. The trade union may be allowed to oppose him and to protect the worker, because the employer thinks that union opposition may be led to play its part in achieving genuine cooperation...

The theory which lies behind the modern progressive employer's approach to industrial democracy is not pure paternalism, for he accepts independent trade unionism. But it contains, and must contain, elements of paternalism. 
Leadership in the common effort comes from above. The pressure is not from below. Progressive management seeks to draw its employees into an intelligent cooperation in its undertaking. Independent trade unions are accepted in the hope that they may play their part in achieving this end. But since unions must remain outside the undertaking to maintain their independence, since they must remain a permanent opposition, they cannot take the lead in this and they must, for the same reasons, avoid complete assimilation to the management's purpose.

Pluralism, of course, as Hyman (1978) noted, is an inherently pluralistic concept. As Purcell (1987) has recently argued, firms that adopt what appears on the surface to be a pluralist approach can differ significantly in their attitudes to unions. Some acknowledge unions but in what remains a fundamentally antagonistic way. Others seek to "emphasize dialogue, understanding and cooperation" (1987, p.535). The pluralist doctrine needs further analysis if it is to provide a framework useful to senior managers seeking an appropriate employment philosophy. Furthermore, as Purcell suggests, the whole Foxian distinction between unitarism and pluralism falls down on the fact that it treats these categories as mutually exclusive and fails to distinguish between management's attitude to trade unions, on the one hand, and employees on the other.

\section{Human resource management}

Contemporary management thought in respect of the employment relationship is increasingly dominated by the notions associated with the term "human resource management" (HRM). While some have simply adopted the HRM term in a generic sense and therefore in a way that does not indicate how thinking has departed from earlier traditions, another line of argument (Beer et al., 1984; Boxall and Dowling, 1990) sees $\mathrm{HRM}$ as emphasising the need to take an investment-oriented and strategic approach to employment relations at the level of the enterprise. Emphasis is placed on the importance of developing human capital. The classical assumption of management accountancy in respect of expenditure on employees (i.e. that it is of a revenue rather than a capital nature) is therefore challenged. The strategic approach calls for the development of a firm-specific human resource strategy which is integrated with strategic management, worked out in the light of an array of stakeholder interests and critical environmental factors and expressed in a consistent set of policy signals. (Boxall, 1990a; Boxall and Dowling, 1990). It therefore seeks to draw human resource policies more fully into the realm of general management and draw general managers more fully into the development of human resource policies.

As a framework for thinking about good employment behaviour, the HRM approach has 2 advantages over industrial pluralism. First, it has a much more sophisticated (though not unproblematic) grip on the relationship between product market strategies and employee relations policies (Schuler and Jackson, 1987). Second, it stresses the importance of investment in human resources as well as the importance of building healthy industrial/human relations. In effect, it takes the position that the traditional focus of industrial relations practice and scholarship - the establishment of employment "rules" that generate workforce "compliance" - is no longer a sufficient basis for management's needs or for analysis of the system. In the light of escalating competitiveness in product markets, the ascendancy of the knowledge-based economy and the demographic and attitudinal changes in the labour market, management increasingly needs a framework which acknowledges the relevance of a more sophisticated set of goals - commitment, flexibility, innovation and the like (Beer et al., 1984; Guest, 1987; Boxall and Dowling, 1990). HRM offers much more specific help to practitioners in relation to issues such as skill formation and individual employee development and retention than can be found in the classical pluralist approach. 
Before we leave this overview of private sector management thought, a general point must be made about all of these philosophies. To borrow a metaphor from Herbert Simon, they are all examples of "bounded" goodness. There is no notion of unbounded employer goodness in the private sector. Employers are not employers first and foremost, they are business people. This means that even the most benevolent employer (by whatever standard one applies) will at times have to resort to "hard" commercial decisions which lead, for example, to workforce reduction or a period of belt-tightening in wages and conditions. A good employer will weather a strike without caving in where it is important to do so (Purcell, 1981). By failing to take such decisions when they are called for, of course, the "good" employer runs the risk of losing the opportunity to be any sort of employer. The obvious lesson for individual employees is the need to take thought for one's own career development and what might be called "personal labour market strength". To rely exclusively on one employer's benevolence or restrict one's skill development exclusively to skills valued by one firm would be very shortsighted.

The argument that shall now be advanced in this paper is that unbounded goodness is also unrealistic in the public sector. Whatever the good employer concept means in the context of the contemporary New Zealand public sector it cannot mean some sort of undisciplined "warm fuzzy" notion. This, of course, is obvious to anyone who has lived through the restructuring of the last few years.

\section{Public sector traditions}

In respect of both Britain and New Zealand it is easy to identify 3 broad phases of thinking in relation to public sector personnel management and industrial relations. Again, the intention is not to describe these philosophies in depth but to point to the trend in thought.

\section{Historic patronage}

The earliest traditions of public sector personnel management were built around "offices" granted by the Crown, a system which lasted well into the eighteenth century (Fredman and Morris, 1989). In the UK, the dismantling of patronage is associated with the Northcote-Trevelyan Report of 1853 which recommended competitive examinations at entry and promotion on merit (Wilenski, 1986; Fredman and Morris, 1989). In New Zealand, the watershed date is 1912 which saw the report of the Hunt Commission and the Public Service Act (Robertson, 1974; Deeks and Boxall, 1989).

\section{Weberian bureaucracy}

Patronage was replaced with the notion of a "salaried, permanent and politically neutral civil service" (Fredman and Morris, 1989, p.13) which grew to bear the hallmarks of a Weberian bureaucracy.

In Australia, the Coombs report (1976) on government administration (quoted in Wilenski, 1986, p.203) defined the career service as meaning:

(a) recruitment by merit (however defined and determined) to a

(b) unified service (intended to mitigate the evils which result from a fragmentary service) subject to

(c) independent, non-political control of recruitment and of the conditions of employment; and where the rights of career public servants are protected by 
(d) regulations which discourage the recruitment of "strangers" to positions above the base grade, and by

(e) legislated protection against arbitrary dismissal (termination being only for cause and by due process).

\section{And exhibiting}

(f) a hierarchical structure of positions defined by

(g) a regular system of position classification of salaries (with incremental advancement within the salary ranges of particular positions), with the career public servant rising through this hierarchy of positions according to

(h) a system of promotion by merit subject to

(i) a system of appeals against promotions (designed to ensure that justice is seen to be done) - the final reward for long and loyal service being

(j) a distinctive retirement and pension system.

This description fits equally well the situation that prevailed in New Zealand from the Public Service Act 1912 through the State Services Act 1962 and up to the reforms of the fourth Labour Government (Martin, 1988, p.13-14). However, the description does not completely define the model. To it must be added the elements of "fair relativity" in pay with respect to the private sector, a relatively consultative approach to industrial relations management in the context of compulsory arbitration, and state leadership in respect of equal pay and equal employment opportunity. That this sort of system has broken down in the UK and New Zealand under the weight of a desire to streamline the public sector and a sustained critique of the presuppositions of the career service model is no longer news.

\section{Accountable management}

The new model adopted in the UK by the Thatcher administration and by the fourth New Zealand Labour Government might conveniently be labelled "accountable management" to borrow a term first used by the Fulton Committee in the UK in 1968 but not fleshed out comprehensively until the advent of the more competitive economic conditions of the 1980s with their concomitant pressure for public sector restructuring. The notion of accountable management in the public service stands alongside a determination to corporatize and, as far as possible, privatize state trading activities (Boston, 1987, 1988; Deane, 1989a, 1989b). Both strands of public sector reform are designed to reduce excessive layers of administration and excess staffing and pinpoint accountability for results in a way that improves the efficiency of the state sector. Chief executive and SES contracts under the State Sector Act are a prominent feature of the new "management culture". So is the power of the government to decline the recommendation of the State Services Commission in respect of a chief executive appointment (s.35), a power which has recently been exercised in relation to the Ministry of Defence (Boston, 1990).

As in the private sector, then, the ascendancy of "accountable management" makes it clear that the good public sector employer must be regarded as exhibiting "bounded" goodness. Goodness is bounded by a concern to keep the size of the state within economically sustainable limits, to ensure it behaves commercially where it engages in commercial activity and to make executive accountability more readily manageable through the practice of negotiating specific performance agreements rather than subscribing to the notion of a "unified career service". This doesn't mean, of course, that individuals will be unable to develop powerful public service careers. The large organizations with significant job opportunities and the strong networks are still there. 
However, public service careers will take on more of the characteristics of private sector careers - most notably, specific performance contracts, performance-related pay and the need for individuals to take ultimate responsibility for their own employment security (through, for example, developing flexible skills and experience and a track record of respected achievements).

\section{The advent of the State Sector Act 1988}

The fourth Labour Government used 2 main legislative vehicles to advance its model of accountable management - the State-Owned Enterprises (SOE) Act 1986 (which corporatized certain state trading entities and laid the basis for subsequent privatization) and the State Sector Act 1988 which codified its new attitude to employment relations in the public service. The economic, political and ideological forces that paved the way for these reforms, along with a variety of perspectives on their desirability, have received substantial attention (Boston, 1987, 1988; Brosnan and McCarthy, 1988; Deane, 1989a, 1989b; Deeks and'Boxall, 1989; Harbridge and Walsh, 1989; Martin, 1988, Mascarenhas, 1988; Scott and Gorringe, 1989; Scott, Bushnell and Sallee, 1990; Walsh, 1989; Walsh and Fougere, 1989; Walsh and Wetzel, 1990). The intention of this article is not to review these works in depth. What is important, however, is to acknowledge first that the insupportable size of the fiscal deficit in New Zealand made reform of the state sector inevitable (Martin, 1988). Such reform was seen as essential within the broader context of economic restructuring and was targeted not only by Roger Douglas but also by David Lange and Geoffrey Palmer (Boston, 1987). Second, certain ascendant ideological forces, principally Treasury's advocacy of public choice theory and the "new institutional" economics, provided this reform mandate with its characteristic shape (Boston, 1987; Martin, 1988; Scott and Gorringe, 1989; Scott et al., 1990). Economic necessity and a government committed to acting on it ensured that reform would take place. The nature of those reforms as they affected employment relations in the state - called here "accountable management" - are the outworking in legislation of ideas associated (primarily) with public choice and agency theory (this is made most explicit in Scott and Gorringe, 1989). The way in which the Labour Government pushed through these reforms without a robust consultative process has been described by Walsh (1989). Again, this is not the issue in this article although it clearly undermined the Government's credibility in terms of its own commitment to consultative management. The purpose of this article is to analyze the implications of the good employer provisions as written into law.

\section{The good employer principle - an exploration}

Our task is to develop a theory of the good employer which operates within the context just outlined, observes the specific provisions of the Act and stands up as a coherent framework for management action. This is no easy matter.

\section{Assumptions}

The tensions embedded in the notion of bounded goodness are apparent in the Act. How are public sector managers to steer a course through this terrain? Before identifying important processes and policies, it is vital to make certain assumptions about "good employer attitudes". The Act itself does not set out explicit assumptions but any chief executive who wishes to comply with it will find it difficult to do so unless able to work from some logically related principles. 
Arguably, the State Sector Act requires chief executives to embrace an employing philosophy which simultaneously recognizes both individual and collective rights. The Act is pluralistic in the sense that union recognition is part-and-parcel of its framework and its integration within the Labour Relations Act. 1 At the same time, however, the State Sector Act (naturally) goes much further than the Labour Relations Act in specifying the way in which the Government expects its chief executives to manage employment relations. Through its provisions for chief executives and SES members a framework for the management of managers is inserted in the Act. And through its concern for EEO, impartial selection and individual development a number of expectations in respect of individual treatment are aired. All in all, it can be argued that the Act implies the following kind of assumptions:

(a) Employees have legitimate interests which they define themselves.

(b) To be a good employer, one must

(i) seek to understand the interests of employees,

(ii) recognize the right of employees to choose how to express their interests,

(iii) seek to maximize one's common interests with employees,

(iv) seek to resolve conflict of interest with employees in ways that are compatible with enterprise effectiveness and (as far as possible) the advancement of employee interests and

(v) seek to take a long term "strategic" approach to employment relations which is integrated with general management and expressed in a consistent set of policy signals.

These assumptions, then, act as my response to s.56(2) - to the need to adopt a position on what is "generally accepted as necessary for the fair and proper treatment of employees in all aspects of their employment". They enable me to integrate what is actually specified in the Act within the broader framework that is not made explicit but which the statute recognizes is necessary. Section 56(2) indicates that good employer behaviour should not be confined to a legalistic conformity with what is specified in the statute. Something greater (quite rightly) is required. Here, then, are the implications of my assumptions and their relationship to the specific provisions cited in the Act. The analysis should make it clear that the Act provides chief executives with important areas of "strategic choice".n

\section{Process and policy implications}

Internal communications First of all, this analysis is based on the view that employees define their own interests and decide how to express them. This means that the good employer must study the views of the employees and build strong internal communications. Regular team briefings and feedback sessions, joint consultative committees, workforce surveys, upward reporting on management performance, exit interviews and regular performance appraisal and career development reviews are examples of the sort of formal mechanisms employers use to give effect to this proposition (Rothwell 1990). Management training to improve informal interpersonal skills is also common. While none of these mechanisms is specified in the State Sector Act, it takes little effort to see that the general concept is strongly supported in contemporary employment practice (witness, for example, the growth of team briefing in New Zealand manufacturing in recent years). To be good at employing, one must build strong, direct lines of communication with employees and avoid the making of inappropriate

1 This article was completed prior to the passage of the Employment Contracts Act 1991 and the repeal of the Labour Relations Act. 
assumptions about what employees want. Naturally, the manifestations of this principle and the extent to which they are successful will vary.

Union-management relations The philosophy outlined also means that the good employer recognizes the union or unions that their employees choose. Conversely, they respect the right of employees not to choose unionization. More generally, irrespective of whether labour law allows employees to choose their own bargaining agent, the good employer works within whatever legislative framework prevails to create a basis for mutual respect in management-union relations and supports the role of the union in giving voice to employee interests. The objective is to build what some have called "mature adversarialism" (Adams, 1989). Besides a positive approach to collective bargaining, this implies the development of joint consultation and joint problem solving to maximize shared interests and shared energies. It may well involve other forms of joint decision-making that the parties deem appropriate. In contrast, immature adversarialism focuses only on conflict of interest and is characterized by rigid defence of "prerogatives" on the one hand and low trust responses on the other. One interpretation of post-reform industrial relations patterns in the state sector generally is to suggest that while some state entities have made progress towards mature adversarialism, others have so far exhibited an immature style. The latter, seeking to distance themselves from what they regard as historically uncommercial industrial relations approaches, have not yet achieved a union-management relationship in which both conflict and cooperation play an appropriate role.

The creation of joint working parties on such matters as new job evaluation and performance appraisal systems is an example of good employment practice in the state. Of course, it must be remembered that the concept of "bounded goodness" outlined earlier implies that, like the union, management must "reserve" its position in certain matters and at certain times. The good employer cannot make an unreasonable commitment to a job or pay structure which has become inefficient or insupportable, for example. Thus, as indicated earlier, it is entirely possible that a good employer in the state will find it necessary to "draw a line" at some point and may weather a strike over it.

Staff development and work design When it comes to staff development and work design policy (which must be considered in tandem), the principles I have outlined imply that the good employer will seek to provide strong incentives to employee skill development and will seek to maximize the intrinsic interest of work. This is based on the view that neither party has an interest in traditional job demarcations and skill-static careers. If New Zealand business is to compete effectively in the globalized economy, a high skill path is likely to be far more effective than a low skill one (Callister, 1990). The public sector must mirror this approach and encourage it. The positive contribution of the state sector reforms in this context is the creation, by and large, of a single industrial document in each department. Such documents, as opposed to service-wide occupational classifications, enable the parties to adopt a more radical approach to work design and career path construction. The parties, of course, must respond to this freedom. A question mark must hang over the Act in terms of whether it provides sufficient incentive for them to do so. While the Act talks of "opportunities for the enhancement

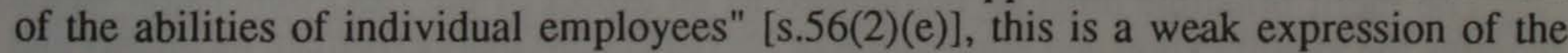
skill formation imperative. It means that, under the statute, departments can be expected to vary substantially in the sophistication of their training and development policies. Having said that, the mere delivery of formal training and development programmes does not prove that worthwhile learning and skill formation has occurred. If chief executives are to be assessed adequately in this area, some sophisticated thinking will be required in terms of appropriate measures. And, if the Act fails to stimulate an appropriate climate of lifelong learning that builds and sustains an excellent public service, it must be seen to have failed substantively. 
It must be noted, in this context, however, that the Act does recognize the vital importance of management development in respect of the SES (s.47 and 55). Here it is critical that individual chief executives and the State Services Commission are able to forge the kind of relationship where there is an appropriate balance between management development within departments and across them. The issues involved are similar to those experienced in multi-divisional companies which must develop general management talent for the sake of the group while simultaneously serving the needs of divisional chief executives. As Evans et al. put it (1989, pp.137-138):

...a serious problem for corporate human resource management is enlisting the cooperation of local managers in identifying and releasing persons with potential. There is little natural incentive for them to do so: their most talented individuals will be creamed off by the corporation, disappearing into other subsidiaries or parts of the world...

Merit-based decision making, EEO and the partnership response In any notion of the good employer, individual personnel decisions (such as appointments and promotions) must be based on merit. In this sense, merit means the use of criteria which can be proved to be relevant to the effective performance of the position and which are not based on untested assumptions. Untested assumptions frequently contain sex, race and disability bias and, in any event, are an uncommercial approach to personnel management. Of course, it should be recognized that some organizations use the merit principle to mean "suitability for a career" in the enterprise and do not restrict it to suitability to the specific position. The State Sector Act takes the latter course (see the wording in s.60) although it does require chief executives to ensure that all employees exhibit "concern for the public interest" (s. 56(3)). The issue can be dealt with, of course, by identifying certain generic departmental criteria and inserting them in all person specifications. One such generic criterion might be to do with the learning orientation of the candidate (in order to appoint only those who have the ability and motivation to keep learning). A focus solely on "merit for the specific position" runs the risk of being shortsighted and encouraging a static attitude to skill formation (which works against the dynamic approach advocated in the previous section). It increases the likelihood of redundancy rather than retraining where the position disappears in the course of technological change.

Under this general heading, there is also a delicate set of issues for departments in regard to the balance between internal and external recruiting for positions above the base recruitment level. Obviously, organizations which always appoint "outsiders" to the top positions demoralize internal talent. At the other extreme, organizations which attempt to recruit only at the base level and promote strictly from within run the risk of creating a "clone-set" rather than a robust corporate culture - a problem recognized at IBM, for example (Evans et al., 1989). Somewhere, in between, a balance of policies must be struck that preserves incentives in the internal labour market but draws in outside talent where it can make an important contribution. The demise of the unified career service requires departments to find an appropriate balance in their context but there is no doubt that this will require some experimentation and soul searching.

The merit principle must be recognized as an aspect of the EEO dimension which requires the identification and elimination of barriers (s.58) that perpetuate inequality and which implies specific measures to deal with particular employment requirements (such as childcare places). It must also be read in conjunction with the requirement in the Act and in Te Urupare Rangapu for personnel policies that recognize the aims, aspirations and employment requirements of the Maori people and the need for greater involvement of the Maori people in the public service. This requires some sophisticated working through of issues and formulation of specific strategies in individual departments. One obvious practical implication is the development of recruitment procedures that ensure that 
members of the target groups have the information, encouragement and confidence necessary to apply for positions. Clearly, then, section 61 of the Act ("obligation to notify vacancies") should not be read in a narrow fashion. Rather, the objective should be to build a departmental recruitment process that attracts, as far as possible, a representative group of suitable applicants who then compete for the position against the appropriate criteria. Furthermore, while the selection criteria must not be compromised and while key assertions made by or on behalf of any candidate must be verified (Boxall, 1990b), the selection process itself can be made more appropriate to the needs of different target groups without undermining its fundamental consistency. The working out of the merit principle clearly implies a commitment to building effective performance planning and appraisal systems. Formal performance planning and appraisal plays a crucial role in underpinning decisions on individual training and development and the allocation of individual rewards (such as performance-related pay and promotions) (Fig 1).

Figure 1: The individual human resource cycle

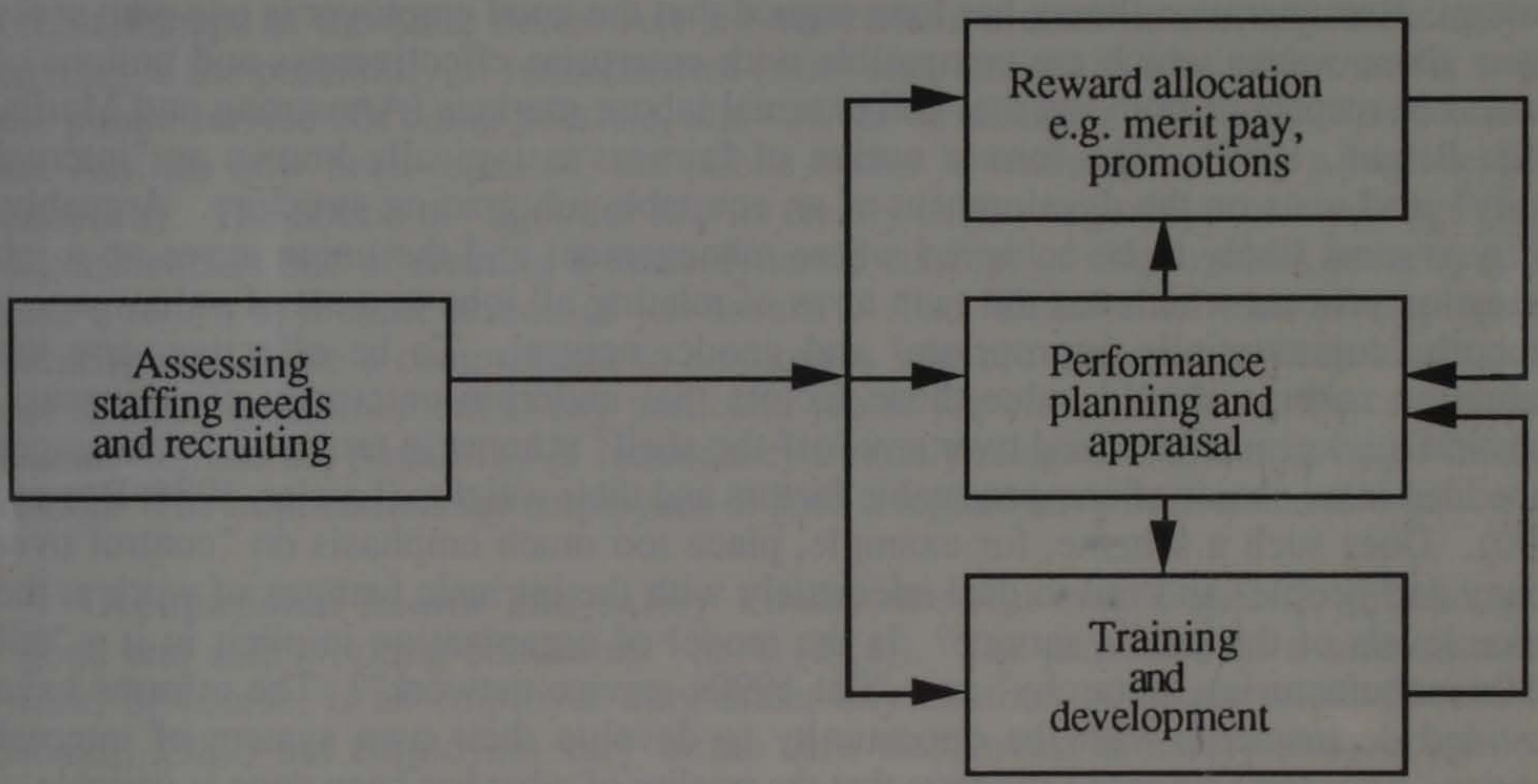

Source: Boxall and Sisley (1990).

Litigation and legislative development in the United States since the landmark Civil Rights Act (1964) has thrown the spotlight on the methods employers use to make decisions about individual rewards and development (Bernardin and Cascio, 1988; Martin et al., 1989). Informal appraisal systems are not generally defensible in EEO terms. Wherever an employer fails to analyze the demands of positions (ideally through participative job analysis) and provide employees with specific performance criteria, their selection, pay, promotion and development decisions will be suspect. A cornerstone of any EEO policy must be a commitment to spell out rational and equitable performance criteria so that individual personnel decisions become transparently consistent and appropriate. This builds employee trust in "the system". It serves to prevent grievances and demotivated employees. The joint working party approach being taken by the PSA and management in public service departments in this area (as noted earlier) is an example of good employment practice in terms of both policy and process. Of course, as in other areas of HRM, no specific system will last forever but the joint working party approach 
enables both union and management to build the expertise and process skills that will enable them to modify and redevelop systems over time. As a rough rule of thumb, performance criteria based on a careful process of job analysis can be expected to last for 3 to 5 years but must then be subject to review.

Finally, it should go without saying that any merit-based personnel management decision should stand up to the scrutiny of employee complaints and grievances. In respect of appointments, the Act requires each chief executive to put a review process in place (s.65). Although not specifically mentioned in the Act, any decision arising out of performance appraisal should be appealable through a process which has the support of the union. The objective of the good employer, of course, is not simply to comply with "due process" in these matters, but to eliminate the causes (for example, irrational criteria and inequitable application of criteria) that give rise to them.

Pay policies The Act is silent on pay policy except in so far as it empowers the State Services Commission to negotiate conditions of employment "in consultation with the chief executive of each department affected" (s.68). While one would expect to see pattern bargaining across the public service in terms of the size of annual pay increases, this should not mask the important area of strategic choice that exists in remuneration strategy. Remuneration theory has long argued that the good employer is one who seeks to pay those wages which are compatible with enterprise effectiveness and notions of fairness in respect of both internal and external labour markets (Armstrong and Murlis, 1988; Brown, 1989). The former notion of fairness is typically known as "internal equity" and rests on the development of an equitable job grading structure. Arguably, equity is most likely to be achieved where management and the union agree on a job evaluation process which has the twin aims of relating all jobs to a set of values which are both "commercially appropriate" and gender neutral. To be effective, any job evaluation scheme should value those factors that underpin enterprise effectiveness. Question marks must be raised over any "off-the-shelf" scheme in terms of the messages embedded in its choice of compensatable factors and their weights (Lawler, 1986; Bowey, 1990). Does such a scheme, for example, place too much emphasis on "control over money and people" and fail to deal adequately with the intrinsic features of work at the senior levels of the public service? Is the model of organization implicit in it a "tall 1950s manufacturing hierarchy" or a "flat 1990s service network"? The reforms have provided departments with the opportunity to develop their own system of internal equities. Anecdotal evidence suggests that the quality of what has been done is variable.

The second dimension of fairness is to do with the external labour market - typically known as "external competitiveness" or "external equity". This requires a methodology for linking the internal job structure to "the market". Of course, the notion of "the market" is far from straightforward (Rynes and Milkovich, 1986) and a variety of "policy lines" are possible in terms of aligning the organization with "it". While a good employer may subscribe to one or more general salary surveys to gain market information, there is no substitute for conducting one's own data gathering in relation to the causes of recruitment and retention difficulties. Enterprise effectiveness may justify the payment of temporary market factor allowances to particular occupational groups. This approach is preferable to solutions which undermine the integrity of either the job evaluation or the performance appraisal system.

There is, of course, a third dimension of fairness - "performance-based equity" which has historically been important in the management of executives in the private sector (Boxall and Sisley, 1990). The public sector reforms have encouraged departments to develop performance-related pay through the mechanism of "ranges of rates". Performance-related pay, where appropriate and where appropriately implemented, can improve both efficiency and equity. It does this primarily by requiring the specification of performance goals or standards (often for the first time) and structuring work feedback around them. This can improve role clarity and motivation. It also allows room to 
attract and reward high performers and thus retain them and allows those with "broken service" or "outside experience" to be paid according to their contribution and not according to their seniority. The effort required to make "merit pay" work, however, should not be underestimated. It depends critically on management's commitment to build and support a sophisticated performance appraisal system (see above). Employees must perceive the proposed merit pay system, in terms of both design and implementation process, to be fundamentally more equitable than what it is attempting to replace. In some cases, a careful study of the particular issues and context will drive the organization towards skill-based pay or a mixture of performance and skill-based pay. The state sector reforms have the virtue of allowing departments some freedom in what is usually an evolutionary process of experimentation.

Because no pay structure lasts forever, what is important is that departments should build their own skills in respect of pay system design. In this area, a track record of consultation and healthy industrial relations is vital to the ability to keep improving pay systems over time. Or to put it another way, process and policy cannot be separated with impunity.

Employment security The notion of the good employer contained in the original shape of the State Sector Act did not contain a commitment to job security. It envisaged the possibility of redundancies (s.66) and, subject to a suitable transfer within the public service not being possible, allowed for termination. Although that section of the Act has now been repealed, the public sector is characterized by a high level of insecurity. The notion of "a job for life" is clearly dead. Arguably, the challenge facing departments is one of creating a more dynamic concept of employment security rather than a return to a static notion of job security. The fundamental idea of employment security is to make a commitment to employees who are prepared to keep learning but not to make a commitment to any particular job or job class. Even so, the commitment cannot exclude the possibility of redundancy but only relegate it to the status of the final option. The implications for employees of such a regime have been noted above.

Occupational health and safety Finally, the Act makes specific provision for "good and safe working conditions" (s.56 (2)(a)). The provision of a safe system of work, of course, is an employer duty under any contract of employment (Deeks and Boxall, 1989) but employers vary in the care they invest in safety and occupational health. It is not controversial to suggest that a good employer should be in the vanguard in these respects. In the public service, one would expect to see measures to deal with the problems of "sick buildings", for example. One would also expect to see employees provided with access to independent advisory resources (such as chaplaincies and psychological services).

\section{General Framework}

A discussion of specific processes and policies always runs the risk that we won't be able to "see the wood for the trees". A typology, such as that outlined by Purcell and Gray (1986), is useful for identifying the general theme underpinning employee relations (where one exists). 
Figure 2: A typology of management "styles" in employee relations

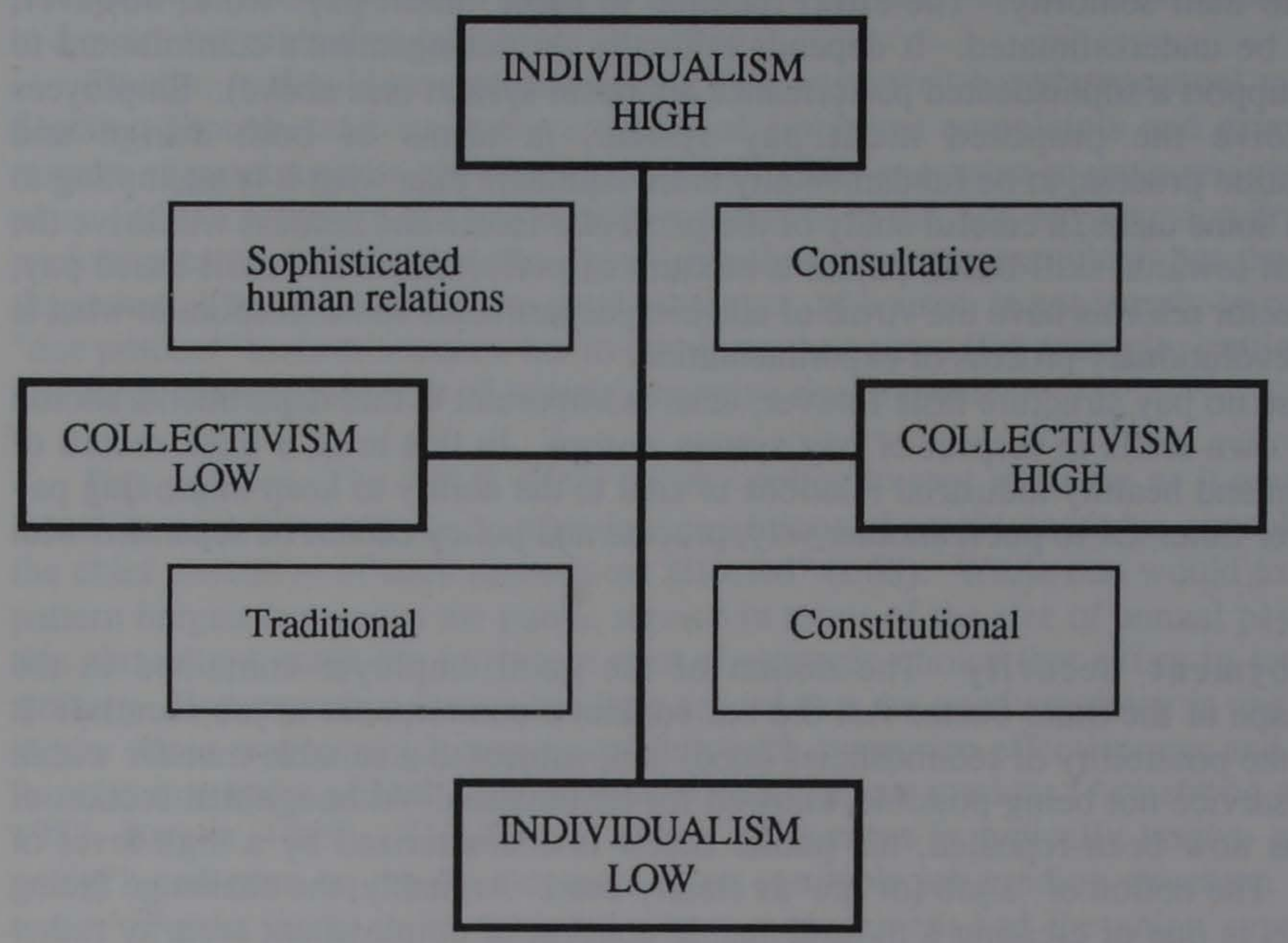

Source: Purcell and Gray (1986); Purcell (1987).

In this framework (figure 2 and table 1), individualism "refers to the extent to which the firm gives credence to the feelings and sentiments of each employee and encourages each employee's capacity and role at work (Purcell, 1987, p.536)". Collectivism "concerns the extent to which the organization recognizes the right of employees to have a say in those aspects of management decision-making which concern them (Purcell, 1987, p.538)." 
Table 1: Management style toward employee relations

Title Description
Most likely to occur in these occurrences
Expected role of central personnel management
Traditional Labour is viewed as a factor of production and employee subordination is assumed to be part of the "natural order"of the employment relationship. Fear of outside union interference. Unionization opposed or unions kept at arm's length.

\section{Sophisticated} human relations term contract or sub-contract labour) viewed as the

\section{Employees (excluding short-} company's most valuable resource. Above average pay. Internal labour market structures with promotion ladders are common with periodic attitude surveys used to harness employees' views. Emphasis is placed on flexible reward structures, employee appraisal systems linked to merit awards, internal grievance, disciplinary and consultative procedures and extensive networks and methods of communication. The aim is to inculcate employee loyalty, commitment and dependency. As a byproduct these companies seek to make it unnecessary or unattractive for staff to unionize.

Consultative Similar to the sophisticated human resource companies except that unions are recognized. The attempt is made to build "constructive" relationships with the trade unions and incorporate them into the organizational fabric. Broad-ranging discussions are held with extensive information provided to the unions on a whole range of decisions and plans including aspects of strategic management,
Small owner-managed companies (or franchise operations). Product markets often highly competitive with the firm having a low share leading to emphasis on cost control and low profit margin.

American-owned single industry, large, financially successful firms with a high market share in growth industries (electronics/ finance sector).
Few personnel specialists.
Strong central personnel departments developing policies to be adopted in all areas of the company.
British/Japanese-owned single industry companies which are large and economically successful, often with a high market share. Companies with relatively low labour costs (process industries) direction when often adopt this style. required.
Central personnel departments produce policy guidelines or precepts providing advice and central 
but the "right of last say" rests with management. Emphasis is also placed on techniques designed to enhance individual employee commitment to the firm and the need to change (share option schemes, profit sharing, briefing or cascade information systems, joint working parties, quality or productivity circles/councils).

Constitutional Somewhat similar to the traditionalists in basic value structures but unions have been recognized for some time and accepted as inevitable. Employee relations policies centre on the need for stability, control and the institutionalization of conflict.

Management prerogatives are defended through highly specific collective agreements and careful attention is paid to the administration of agreements at the point of production. The importance of management control is emphasized with the aim of minimising or neutralising union constraints on both operational (line) and strategic (corporate) management.

Single industry companies with mass production or large batch production requiring a

large unit size of operation. Labour costs form a significant proportion of total costs. Product market conditions are often highly competitive.
Relatively strong emphasis on the central personnel auditing/control function.

Source: Purcell \& Gray, 1986

In terms of the arguments outlined earlier, one would expect public service departments to seek a position that is broadly consistent with the "consultative" approach, that is one that attempts to accommodate both high concern for the individual and recognition of collective representation. However, as emphasized earlier and as recognized in table 1 , such an approach will be bounded by efficiency considerations. It must be admitted that few public service departments will be able to marshall the resources associated with the most successful large scale private sector corporations who adopt this strategy. Pay levels, for example, are unlikely to match the private sector leaders. And, of course, it must be admitted that the leading private sector corporations who adopt this strategy are able to build it up comprehensively over a long period of time, largely irrespective of whatever political party is in power. This is obviously not the situation in the public sector.

The other patterns shown in figure 1 are clearly inappropriate. The traditional style falls short of good employer attitudes. The constitutional style is indicative of much traditional industrial relations management in certain conflict-prone private sector industries (such as construction and transport). Great emphasis is placed on negotiating 
industrial documents that are observed by "the other side" but often there is a lack of sophisticated thinking in respect of the behavioural implications of management style. It falls short of a robust HRM approach where all signals to staff (including those embedded in any collective agreement and the manner of its negotiation and application) are carefully integrated. The sophisticated human relations approach has much in common with the consultative one. Many of the same destinations will be reached by both styles. However, the former style must be discounted to the extent that it is not built on an acceptance of the right of employees to choose how to express their interests.

\section{The assessment of chief executive employment performance}

The principle of holding the chief executive accountable for the quality of personnel management and industrial relations in an organization is a good one. This sends a message about the importance of employment matters, helps to encourage the integration of such matters into the realm of general management and recognizes the role of chief executives in determining reporting levels, building an executive team, spearheading policy development and allocating resources. It recognizes a key premise in the theory of HRM.

Having said that, the demands placed upon chief executives by the Act are awesome. On any reading, the Act requires the simultaneous achievement of effectiveness (in terms of contracted outputs) and efficiency (in terms of resource management) on the one hand and equity and integrity goals on the other (see s.35(12)). This is a tall order. As argued in this paper, it implies an understanding that the notion of the good employer is a "bounded" one. The State Sector Act must be regarded as a statute which contains both personnel management reforms and financial management ones. As Walsh and Fougere (1989, p.221) put it:

The State Sector Act had dual policy objectives. On the one hand, it was intended to improve the effectiveness and efficiency of the core state sector and thus help the Government realise its public sector management policy objectives. On the other hand, the Act was intended as an instrument of fiscal management. It abolished the AGA and compulsory arbitration and eliminated block service-wide negotiations on conditions of employment. All workers were now required to negotiate pay and conditions in direct bargaining with employers. This made "hard budgets" possible for the first time in the state sector..."

Any assessment of a chief executive's performance as a good employer must take account, then, of "the need to take the hard decisions" where appropriate. The fourth Labour Government has engineered a reform of the state sector which has produced major redundancies and placed chief executives within a framework which recognizes diminished security and scarce resources. Whether this new framework brings about a stable and effective regime of employee relations in the public service is as much a test of the Act as it is of chief executives.

In my view, the critical test of chief executives is whether they can bring about a strategic approach to human resource management in their department. This requires the building of a vision within senior management of the kind of employer the department can and should be, given its particular traditions, projected mission and the specific opportunities and problems it faces as an organization and an employer. This is easier said than done. It implies a sophisticated dialogue and debate within management itself in respect of alternative employment policies. It also implies a fierce commitment to draw the individual objectives and partial paradigms of particular managers and human resource specialists into a model of employer behaviour which exhibits a consistent set of themes. The reforms of the public sector contain the potential for departments to "fire off 
in all directions". Bringing the pieces together into a coherent framework is a truly general management task.

It is also important to realize that the greatest corporate exponents of HRM have not attained their leadership as employers overnight. Worthwhile change in HRM is a longterm endeavour that is ill-at-ease with the typical focus in Western organizations on short reporting periods and short-term measures (Storey and Sisson, 1990). To expect a chief executive on a 5 year contract to arrive at all the desired policy destinations simultaneously is unrealistic. However, it is reasonable to expect to see positive signs of progress in the processes, programmes and relationships that are deemed necessary. The job itself will never be finished.

\section{Conclusions}

Economic necessity ensured that the fourth Labour Government would reform public sector management. In respect of public service personnel management and industrial relations, those reforms are primarily expressed in the State Sector Act 1988. With its philosophical underpinnings in public choice theory and the new institutional economics, the Act is an expression of "accountable management". The notion of the good employer contained in it must be understood as a bounded one. It is bounded by a concern to keep the size of the state within economically sustainable limits, to ensure it behaves commercially where it engages in commercial activity and to make executive accountability more readily manageable.

Under the Act, chief executives are required to behave as good employers. The Act provides chief executives with considerable strategic choice in giving effect to this requirement. It does not define the term in an exhaustive manner. Rather, section 56 implies that it is the role of each chief executive to develop a customized employing philosophy or human resource strategy in their department. A legalistic implementation of only those items specified in the statute itself would fall short of this implicit standard.

This article has pointed to a number of process and policy domains where chief executives must exercise strategic choice. Interesting questions include the extent to which chief executives will build strong direct communications with employees and the kind of relationships they will seek to build with unions. There are also issues relating to the way in which the merit principle is interpreted - whether in relation to the specific position applied for or in relation to a more dynamic career concept. Similarly, there are questions relating to the balance between internal and external recruitment and in relation to the development of recruitment procedures that uphold EEO principles without undermining the consistency of the selection process. Similarly, there is a substantial area of strategic choice in the area of pay policy. While the notion of compatibility between enterprise effectiveness and the " 3 equities" (external, internal and performancebased) is easily subscribed to, its implementation involves significant choices and considerable determination. And, perhaps most importantly, the area of training and development invites a wide variation of interpretation. To the extent that this regime of public sector personnel management fails to encourage vigorous skill formation, it might be argued that it fails substantively.

Piecemeal perspectives on particular aspects of the employment relationship, of course, fall short of what is necessary to manage a modern workforce in a sophisticated manner. Given the values implicit in the State Sector Act, one would expect to see what Purcell and Gray (1986) define as a general pattern of consultative management emerging in the public service. The critical test of chief executives under this statute is not whether they can push a little here or a little there on fashionable bandwagons but whether they can draw the pieces together into a coherent whole. Satisfactory progress on this criterion should be the primary test of chief executive performance under the Act. 
Sophisticated HRM implies a commitment to building a vision of the kind of employer the department wishes to be and careful attention, over time, to the processes that will implement, review and reshape it.

\section{References}

Adams, R. (1989) North American industrial relations: divergent trends in Canada and the United States. International labour review 128:47-64.

Armstrong, M. and Murlis, H. (1988) Reward management. London, Kogan Page.

Beer, M., et al. (1984) Managing human assets. New York, Free Press.

Bernardin, H. and Cascio, W. (1988) Performance appraisal and the law. In R. Schuler et al. (eds.) Readings in personnel and human resource management. St Paul, West, 235247.

Boston, J. (1987) Transforming New Zealand's public sector: Labour's quest for improved efficiency and accountability. Public Administration 65:423-442.

Boston, J. (1988) From corporatisation to privatisation: public sector reform in New Zealand. Canberra bulletin of public administration 57:71-86.

Boston, J. (1990) Public sector update - appointing a Secretary of Defence. Public Sector $13(3): 5-6$.

Bowey, A. (1990) Redesigning remuneration policy. Paper presented to Longman Professional conference, The revolution in rewards strategy, Auckland and Wellington, May.

Boxall, P. (1990a) Introduction - a function in search of a future. In P. Boxall (ed.) Function in search of a future - perspectives on contemporary human resource management in New Zealand. Auckland, Longman Paul.

Boxall, P. (1990b) Interviews: the steps to success. Management 37(8):54-65.

Boxall, P. and Dowling, P. (1990) Human resource management and the industrial relations tradition. Labour and industry 3 (2 \& 3):195-214.

Boxall, P. and Sisley, D. (1990) The development of performance appraisal and pay-forperformance systems. In P. Boxall (ed.) Function in search of a future. Auckland, Longman Paul.

Brosnan, P. and McCarthy, C. (1988) Public sector pay fixing in Ireland and New Zealand, 1945-85: towards a theory. Labour and society 13:261-282.

Brown, W. (1989) Managing remuneration. In K. Sisson (ed.) Personnel management in Britain. Oxford, Blackwell.

Callister, P. (1990) Tomorrow's skills. Wellington, New Zealand Planning Council.

Clegg, H. (1972) Trade unions as an Opposition which can never become a Government. In W.E.J. McCarthy, (ed.) Trade unions. Harmondsworth, Penguin.

Crichton, A. (1968) Personnel management in context. London, Batsford.

Davies, P. and Freedland, M. (1983) Kahn-Freund's labour and the law. London, Stevens.

Deane, R.S. (1989a) The New Zealand experience. In J. Hyde and M. Porter (eds.). The good fight: essays in honour of Austin Stewart Holmes. Sydney, Allen and Unwin

Deane, R.S. (1989b) Reforming the public sector. In Walker, S (ed). Rogernomics: reshaping New Zealand's economy. Auckland, G P Books. 
Deeks, J. and Boxall, P. (1989) Labour relations in New Zealand. Auckland, Longman Paul.

Eilbirt, H. (1959) The development of personnel management in the United States. Business history review 33:345-364.

Evans, P., Lank, E. and Farquhar, A. (1989) Managing human resources in the international firm: lessons from practice. In Evans, et al. (eds.) Human resource management in international firms. Basingstoke, MacMillan.

Fredman, S. and Morris, G.S. (1989) The State as employer: labour law in the public services. London, Mansell.

Guest, D. (1987) Human resource management and industrial relations. Journal of management studies 24:503-521.

Harbridge, R. and Walsh, P. (1989) Restructuring industrial relations in New Zealand, 1984-1988. Labour and Industry 2:60-84.

Hughes, J. (1990) Labour law in New Zealand. Sydney, Law Book Co.

Hyman, R. (1978) Pluralism, procedural consensus and collective bargaining. British journal of industrial relations 16:16-40.

Lawler, E. (1986) What's wrong with point factor job evaluation? Management review November:44-48.

MacIntyre, A (1987) After virtue: a study in moral theory. London, Duckworth.

Martin D., Bartol, K and Levine, M (1989) The legal ramifications of performance appraisal. In F. Foulkes (ed.) Human resources management readings. Englewood Cliffs, Prentice Hall.

Martin, J. (1988) A profession of statecraft? Wellington, Victoria University Press.

Mascarenhas, R. (1988) Public sector reform in Australia and New Zealand. Paper presented to IASIA Annual Conference, Brisbane.

McGivering, I. (1970) The development of personnel management. In A. Tillet, et al. (eds.) Management thinkers. Harmondsworth, Penguin.

Miller, F.B. and Coghill, M.A. (1961) The historical sources of personnel work. Ithaca, New York State School of Industrial and Labour Relations, Cornell University.

Purcell, J. (1981) Good industrial relations: theory and practice. London, MacMillan.

Purcell, J. (1987) Mapping management styles in employee relations. Journal of management studies 24:533-548.

Purcell, J., and Gray, A. (1986) Corporate personnel departments and the management of industrial relations: two case studies in ambiguity. Journal of management studies 23:205-223.

Robertson, J.F. (1974) Legislation and industrial relations in the public sector. In J.M. Howells et al. Labour and industrial relations in New Zealand. Carlton, Pitman.

Rothwell, S. (1990) Human resources management. Manager update 1:18-27.

Rynes, S. and Milkovich G. (1986) Wage surveys: dispelling some myths about the "market wage". Personnel psychology 339:71-90.

Schuler, R. and Jackson, S. (1987) Linking competitive strategies with human resource management practices. Academy of management executive 1:206-219.

Scott, G. and Gorringe, P. (1989) Reform of the core public sector: the New Zealand experience. Australian journal of public administration 48:81-92. 
Scott, G., Bushnell, P. and Salle, N. (1990) Reform of the core public sector - the New Zealand experience. Public sector 13(3):11-24.

Storey, J. and Sisson, K. (1990) Limits to transformation: human resource management in the British context. Industrial relations journal 21:60-65.

Walsh, P. (1989) A family fight? Industrial relations reform under the fourth Labour Government. In B. Easton (ed.) The making of Rogernomics. Auckland, Auckland University Press.

Walsh, P. and Fougere, G. (1989) Fiscal policy, public sector management and the 1989 health sector strike. New Zealand journal of industrial relations 14:219-229.

Walsh, P. and Wetzel, K. (1990) State restructuring, corporate strategy and industrial relations: state-owned enterprise management in New Zealand. Paper presented to 5th AIRAANZ Conference, Melbourne.

Wilenski, P. (1986) Public power and public administration. Sydney, Hale and Iremonger. 